\section{SUMMARY}

1. 2:6-Dioxa-3:7-dioxobicyclo[3:3:0]octane ('the dilactone') hydrolyses spontaneously and nonenzymically to $( \pm)$-muconolactone; this hydrolysis is rapid above $\mathrm{pH} 7 \cdot 0$.

2. At $\mathrm{pH} 6 \cdot 2-6 \cdot 6$, where the hydrolysis rate is low, extracts of Pseudomonas (phthalate-utilizer), P. fuorescens (A3.12) and Nocardia do not metabolize the dilactone at a rate in excess of its rate of hydrolysis.

3. The dilactone is now considered not to be an intermediate in protocatechuate metabolism by these micro-organisms.

4. Two samples of $\beta \gamma$-dihydroxyadipic acid failed to act as precursors of $\beta$-oxoadipate when used as substrates in the enzyme system which converts protocatechuate into $\beta$-oxoadipate.

D. W. R. gratefully acknowledges the receipt of a research studentship from the University of Wales. The Department of Agricultural Chemistry, University College of North Wales, and the Department of Biochemistry, University of Leeds, are in receipt of grants from D.S.I.R. towards apparatus. Thanks are due to Professor E. L. Tatum and Professor R. Y. Stanier for cultures of Neurospora crassa (wild-type) (SY4a) and Pseudomonas fluorescens A3.12, respectively. We are indebted to $\mathrm{Mr}$ J. Islwyn Davies,
B.Sc., for collaborating in the $\beta \gamma$-dihydroxyadipic acid experiments.

\section{REFERENCES}

Cain, R. B. (1958). J. gen. Microbiol. 19, 1.

Cain, R. B. (1961). Biochem. J. 79, 298.

Cain, R. B. \& Cartwright, N. J. (1960). Biochim. biophys. Acta, 37, 197.

Elsden, S. R. \& Peel, J. L. (1958). Annu. Rev. Microbiol.12, 145.

Elvidge, J. A., Linstead, R. P., Orkin, B. A., Sims, P., Baer, H. \& Pattison, D. B. (1950). J. chem. Soc. p. 2235.

Franzen, H. \& Schmitt, F. (1925). Ber. dtsch. chem. Ges. 20, 590.

Gross, S. R., Gafford, R. D. \& Tatum, E. L. (1956). J. biol. Chem. 219, 781.

Landa, S. \& Eliasek, J. (1956). Chem. Listy, 50, 1834.

Limpricht, H. (1873). Liebigs Ann. 165, 267.

Pankoke, K. (1925). Liebigs Ann. 441, 188.

Przybytek, S. (1884). Ber. dtsch. chem. Ges. 17, 1091.

Ribbons, D. W. \& Evans, W. C. (1959). Biochem. J. 73, $21 \mathrm{P}$.

Ribbons, D. W. \& Evans, W. C. (1960). Biochem. J. 76, 310.

Rothera, A. C. H. (1908). J. Physiol. 37, 491.

Ruhemann, S. \& Elliot, W. J. (1890). J. chem. Soc. p. 931. Sleeper, B. P., Tsuchida, M. \& Stanier, R. Y. (1950). J. Bact. 59, 129.

Wislicenus, W. (1887). Ber. dtsch. chem. Ges. 20, こ90.

Biochem. J. (1961) 79, 316

\title{
Studies on Phospholipids
}

\section{THE DISTRIBUTION OF COMPLEX PHOSPHOLIPIDS IN VARIOUS SPECIES AND TISSUES*}

\author{
By F. D. COLLINS AND VALERIE L. SHOTLANDER \\ Department of Biochemistry, University of Melbourne, Parkville N. 2, Victoria, Australia
}

(Received 21 September 1960)

Collins \& Wheeldon (1957) have advanced evidence for the occurrence in rat liver, ox brain and egg yolk of 'complex' forms of amino-phospholipids and Collins (1959b) has described their separation and characterization by means of countercurrent distribution. The nature of these 'complex' phospholipids has been discussed by Collins (1960), who has presented evidence that they contain a phosphate triester group and at least two atoms of phosphorus/molecule. This paper is concerned with the distribution of these complex phospholipids in rat tissues and in other biological material.

\footnotetext{
* Part 6: Collins (1959a).
}

\section{EXPERIMENTAL}

\section{Materials}

Rats. The livers, brains, hearts, small intestines, kidneys, lungs, spleens and testes of twenty white rats (Wistar strain, body wt. 150-250 g.) were removed, quickly frozen and stored at $-18^{\circ}$ until required. For the additional experiments on the countercurrent distribution of the phospholipids animals were killed as required and the tissue was extracted as rapidly as possible.

Hen's eggs. These were not more than $24 \mathrm{hr}$. old.

Cabbage leaf. Extraction was carried out within $3 \mathrm{hr}$. of collection.

Influenza virus and hen's-egg allantoic membrane. These were received in a frozen-dried condition and were prepared 
by Mr G. L. Ada, Walter and Eliza Hall Institute, Melbourne (Ada \& Perry, 1954).

Human-plasma fraction. A lipoprotein-rich fraction (1 g.) of human plasma (fraction IV-I, Cohn et al. 1946) was used. This was equivalent to 2381 . of plasma and was supplied, frozen-dried, by the Commonwealth Serum Laboratory, Melbourne.

Ox-spinal-cord sphingolipids. A mixture of cerebrosides and sphingomyelin was prepared as described by Carter, Haines, Ledyard \& Norris (1947) and contained $0.77 \%$ of phosphorus and $11 \cdot 8 \%$ of galactose.

Human brain. Samples of human-brain-lipid fractions were supplied by Dr P. Fantl, Baker Medical Research Institute, Alfred Hospital, Melbourne.

Yeast. Fresh compressed yeast was extracted and the lipids were treated as described below.

Freshwater crustacean (Cherix albidus Clark). The live crustaceans were brought to the laboratory, the whole animals were extracted and the lipids treated as described below.

\section{Methods}

The lipids were extracted and caused to react with 1-fluoro-2:4-dinitrobenzene as described by Wheeldon \& Collins (1957). The product was treated with diazomethane and separated into a non-polar and a polar fraction by countercurrent distribution (Collins \& Wheeldon, 1957). On each fraction phosphorus and amino nitrogen ( $N$-2:4dinitrophenyl groups) were determined as described by Wheeldon \& Collins (1957). Ethanolamine and serine were determined on the polar and non-polar fractions of rattissue lipids by the method of Collins \& Wheeldon (1958) and inositol, sugar and acyl ester groups were estimated as described by Collins (1959b).

Choline. The hydrolysis procedure described by Wheeldon \& Collins (1958) when applied to lipids other than those from liver and brain yielded less choline than was obtained by more vigorous hydrolysis. As a consequence analyses reported here were carried out after hydrolysis by heating with $6 \mathrm{~N}$-hydrochloric acid in a sealed tube at $110^{\circ}$ until all the phosphorus was present as inorganic phosphate. This usually required $24 \mathrm{hr}$. but with spleen, heart and lung lipids $48 \mathrm{hr}$. was required. Choline was determined on the hydrolysate as described by Wheeldon \& Collins (1958), except that in the development of the colour the stannous chloride solution was added after the addition of the ethanol.

Phosphatidic acid-like materials. The difference between the total phospholipids in the non-polar fraction and the amounts of phosphatidylethanolamine and phosphatidylserine was used as a measure of the phosphatidic acid-like materials; these correspond to fractions $\mathrm{X}, \mathrm{Y}$ and $\mathrm{Z}$ described by Collins (1959 $b$ ).

Complex phospholipids. In the experiments described in Tables 1 and 2 the complex phospholipids were estimated from the amounts of dinitrophenyl groups in the polar fractions (Collins, 1959 b). The results shown in Table 4 represent the amounts of complex phospholipids as isolated by countercurrent distribution (e.g. tubes 35-120 in Fig. $1 b$ ). Both procedures give the same values for dinitrophenyl groups in the complex phospholipids but only the second gives a direct estimate of their phosphorus content.

Countercurrent distribution of phospholipids. In the course of this work it was desired to examine certain rattissue phospholipids in greater detail. The dinitrophenylated and methylated lipids prepared as described above were separated into an acetone-soluble and an acetoneinsoluble fraction by the procedure described by Collins \& Shotlander (1960), by chromatography on cellulose at $-18^{\circ}$ with acetone. These two fractions were submitted to countercurrent distribution (120 transfers) with carbon tetrachloride-methanol-water $(62: 35: 3 \cdot 15$, by vol.) for the acetone-soluble material and carbon tetrachloride-chloroform-methylene chloride-methanol-water (25:15:10:40: 10, by vol.) for the acetone-insoluble material: the solvent systems are those described by Cole, Lathe \& Ruthven (1953). The volume of each phase was $20 \mathrm{ml}$. and after distribution the contents of the first and every fifth tube were analysed for $N$-2:4-dinitrophenyl groups as described above and phosphorus as described by Collins (1959b).

It was essential that the above-mentioned solvent mixtures were prepared immediately before use and checked for neutrality. The acidity of the solvent mixtures was tested as follows: to $10 \mathrm{ml}$. each of water and of solvent mixture was added $0.1 \mathrm{ml}$. of Universal Indicator (British Drug Houses Ltd.). The carbon dioxide was removed under reduced pressure and the resulting colour in the aqueous phase visually compared with the colour produced in the absence of solvent. If the colour was the same (light green) the solvent mixture was acceptable, otherwise it was rejected.

\section{RESULTS}

Collins \& Wheeldon (1957) showed that a simplified countercurrent distribution of dinitrophenylated and methylated phospholipids yielded two fractions which were designated polar and nonpolar respectively. Collins (1959 $b$ ) has shown that the non-polar fraction contains the phosphatidylethanolamine, phosphatidylserine and phosphatidic acid-like materials and that the polar fraction contains the complex phospholipids. Analysis of the non-polar and polar fractions of rat tissues are shown in Table 1 and in other species in Table 2. In addition to the above-mentioned results, countercurrent distribution has shown the presence of complex phospholipids in the lipids from human brain, yeast and a freshwater crustacean (Cherix. albidus Clark).

The lipids from rat liver, heart and kidneys were studied in greater detail by means of countercurrent distribution. As lecithin and some of the complex phospholipids had similar partition coeffcients in carbon tetrachloride-methanol-water a preliminary separation was necessary, and the chromatographic procedure described by Collins \& Shotlander (1960) 'with cellulose and elution with acetone at $-18^{\circ}$ was used to separate the phospholipid derivatives into two fractions. The acetonesoluble fraction contained all the dinitrophenyl derivatives, some of the choline and some phosphatidic acid-like material. Choline and inositol were present in the acetone-insoluble fraction. 


\section{Table 1. Distribution of phospholipids in rat tissues}

All figures, unless shown otherwise, are molar \% of total lipid phosphorus.

\begin{tabular}{|c|c|c|c|c|c|c|c|c|}
\hline & Brain & Heart & Intestine & Kidney & Liver & Lung & Spleen & Testes \\
\hline Total lipid (\% of fresh tissue) & $10 \cdot 1$ & $2 \cdot 3$ & $4 \cdot 8$ & $3 \cdot 6$ & $3 \cdot 6$ & $4 \cdot 7$ & $2 \cdot 2$ & $2 \cdot 6$ \\
\hline $\begin{array}{l}\text { Total lipid phosphorus ( } \mu \text { moles/g. } \\
\text { of fresh tissue) }\end{array}$ & 82 & $18 \cdot 5$ & $7 \cdot 2$ & 25 & $30 \cdot 7$ & $15 \cdot 0$ & $16 \cdot 2$ & $13 \cdot 9$ \\
\hline $\begin{array}{l}\text { Non-polar fraction } \\
\text { Phosphatidic acid-like material } \\
\text { Ethanolamine } \\
\text { Serine }\end{array}$ & $\begin{array}{r}9 \\
19 \\
4\end{array}$ & $\begin{array}{r}7 \\
17 \\
3\end{array}$ & $\begin{array}{r}6 \\
19 \\
3\end{array}$ & $\begin{array}{r}1 \\
20 \\
6\end{array}$ & $\begin{array}{r}2 \\
13 \\
2\end{array}$ & $\begin{array}{l}3 \\
9 \\
2\end{array}$ & $\begin{array}{r}\mathbf{4} \\
11 \\
2\end{array}$ & $\begin{array}{r}3 \\
16 \\
4\end{array}$ \\
\hline $\begin{array}{l}\text { Polar fraction } \\
\text { Inositol } \\
\text { Ethanolamine } \\
\text { Serine } \\
\text { Choline }\end{array}$ & $\begin{array}{r}2 \\
21 \\
6 \\
39\end{array}$ & $\begin{array}{r}3 \\
17 \\
4 \\
\mathbf{4 6}\end{array}$ & $\begin{array}{r}6 \\
16 \\
3 \\
47\end{array}$ & $\begin{array}{r}6 \\
13 \\
6 \\
50\end{array}$ & $\begin{array}{r}7 \\
11 \\
4 \\
64\end{array}$ & $\begin{array}{r}3 \\
13 \\
2 \\
64\end{array}$ & $\begin{array}{r}4 \\
17 \\
6 \\
58\end{array}$ & $\begin{array}{r}2 \\
12 \\
6 \\
48\end{array}$ \\
\hline Sum of phospholipid components & 100 & 97 & 100 & 102 & 103 & 96 & 102 & 91 \\
\hline
\end{tabular}

Table 2. Complex phospholipids in species other than the rat

Non-polar fractions contain the phosphatidylethanolamine and phosphatidylserine; polar fractions contain the complex phospholipids.

\begin{tabular}{|c|c|c|c|c|}
\hline \multirow[b]{2}{*}{ Sample } & \multirow{2}{*}{$\begin{array}{c}\text { Total lipid } \\
\text { (\% of } \\
\text { wet wt.) }\end{array}$} & \multirow{2}{*}{$\begin{array}{c}\text { Phosphorus } \\
\text { ( } \mu \text { moles } / 100 \mathrm{mg} . \\
\text { of total lipid) }\end{array}$} & \multicolumn{2}{|c|}{$\begin{array}{l}\text { Ethanolamine }+ \text { serine }(\mu \mathrm{moles}) \text { as } \% \\
\text { of total lipid-phosphorus }(\mu \mathrm{g} . a \text { toms })\end{array}$} \\
\hline & & & Non-polar fraction & Polar fraction \\
\hline $\begin{array}{l}\text { Hen's-egg yolk } \\
\text { Hen's-egg allantoic membrane } \\
\text { Influenza virus } \\
\text { Human-plasma fraction } \\
\text { Cabbage leaf }\end{array}$ & $\begin{array}{l}34 \\
12 \cdot 1 \\
38 \\
30 \\
0 \cdot 57\end{array}$ & $\begin{array}{l}26 \\
26 \\
32 \\
24 \\
18\end{array}$ & $\begin{array}{r}7 \cdot 7 \\
16 \cdot 8 \\
23 \cdot 8 \\
3 \cdot 3 \\
13 \cdot 1\end{array}$ & $\begin{array}{r}18 \cdot 1 \\
19 \cdot 5 \\
27 \cdot 8 \\
7 \cdot 1 \\
10 \cdot 3\end{array}$ \\
\hline
\end{tabular}

Table 3. Details of material used for the countercurrent-distribution experiments

No. of animals

Tissue (g.)

Lipid (mg.)

Acetone-soluble derivatives

( $\mu$ g.atoms of P)

Acetone-insoluble deriva-

tives ( $\mu$ g.atoms of $\mathrm{P}$ )

$\begin{array}{ccc}\text { Liver } & \text { Kidney } & \text { Heart } \\ 1 & 4 & 20 \\ 11 \cdot 5 & 8 \cdot 6 & 16 \cdot 5 \\ 544 & 276 & 447 \\ 280 & 126 & 269 \\ 175 & 75 & 133\end{array}$

Table 3 shows the details of the rat-liver, -kidney and -heart lipids which were subjected to countercurrent distribution. The results of countercurrent distribution of rat-liver lipids are shown in Fig. 1 and five main fractions could be distinguished:

(1) In the acetone-insoluble portion the material in tubes 1-5 contained phosphorus but no ethanolamine, serine, choline or inositol and will be designated phosphatidic acid-like material.

(2) Tubes 6-40 in the acetone-insoluble fraction contained phosphorus and choline in the molar ratio of 0.98 and had 1.96 ester groups/g.atom of phosphorus, which are the values expected for lecithin.

(3) In the acetone-insoluble portion the contents of tubes 41-120 are designated minor phospholipids, as there was insufficient material for a detailed analysis. Several fractions could be distinguished and both inositol and choline were present.

(4) In the acetone-soluble portion the contents of tubes 1-20 correspond to the non-polar fraction previously described (Collins, 1959b).

(5) The remainder of the acetone-soluble portion (tubes 31-120) correspond to the complex phospholipid fraction, which clearly contains several components.

The phospholipid derivatives from heart and kidney gave similar distributions, which could be grouped into the same five fractions, but within these fractions some differences were apparent. Although the lecithin peak was in the same position in each case it was found to be skew for the kidney-phospholipid derivatives (see Fig. 1 $a$ ), and this was thought to be due to sphingomyelin. To test this, spinal-cord sphingolipids were treated in the same way as rat-tissue lipids and the acetone-insoluble fraction was distributed in carbon tetrachloride-chloroform-methylene chloridemethanol-water. Most of the material (69\%) was present in the region of tubes 10-50; sugar (as galactose) was maximal at tube 20 and phosphorus at tube 30. Hence it may be concluded that the bulge in the region of the lecithin peak is indicative of sphingomyelin and this fraction will be designated lecithin and sphingomyelin. 
Differences were noted in the distribution of the minor phospholipids but the small amounts present make a comparison difficult at this stage. The complex phospholipid derivatives were distributed in

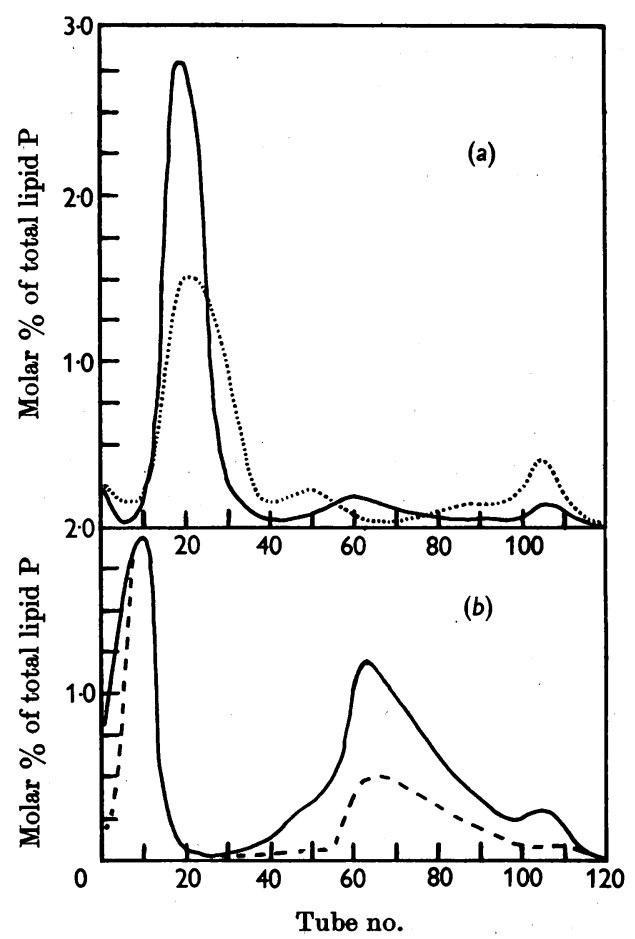

Fig. 1. Countercurrent distribution of rat-liver-phospholipid derivatives. (a) The acetone-insoluble fraction was distributed in carbon tetrachloride-chloroform-methylene chloride-methanol-water. (b) The acetone-soluble fraction was distributed in carbon tetrachloride-methanol-water. Every fifth fraction was analysed for phosphorus (-) and dinitrophenyl groups (.....). For comparison the distribution is also given for the acetone-insoluble kidney phospholipids in terms of phosphorus (.........). the same region, in each case, but the profiles of the distribution curves differed.

The areas under the curves were summed for each of these five fractions both for phosphorus and for dinitrophenyl groups and the amounts present are shown in Table 3. The total phosphatidic acidlike material represents the sum of the acetonesoluble and -insoluble portions.

\section{DISCUSSION}

The analyses for rat-tissue phospholipids are in good agreement with published data for total phospholipids and choline (Wittcoff, 1951 ; Dueul, 1955; Dawson, 1957; Hanahan, Dittmer \& Warashina, 1957; Marinetti, Erbland \& Stotz, 1958; Sakagami, Shimojo \& Yokoyama, 1959). The inositol content of the rat-tissue lipids is in agreement with that found by Taylor \& McKibbon (1953) for dog tissues and with Dawson (1960) for sheep liver, but is higher than that found by Marinetti et al. (1958) for rat liver and kidney. In recent years, with the advent of improved analytical procedures, several detailed analyses of tissue phospholipids have been published, and these results account for all or nearly all of the lipid phosphorus. By using silicic acid chromatography Hanahan et al. (1957) have examined rat-liver, ox-liver and yeast phospholipids and Sakagami et al. (1959) have studied rat-liver and -heart phospholipids. Marinetti et al. (1958) have analysed the phospholipids of rat liver, kidney, spleen, lung and heart by paper chromatography on silicic acid-impregnated paper. The procedure for the isolation of characteristic phosphate esters by hydrolysis of the phospholipids described by Dawson (1960) has been applied to sheep liver, and these results are included in the present comparison because of the contrast in the analytical method with those of other workers.

Except for testes the results shown in Table 1 account for all the lipid phosphorus within $4 \%$.

Table 4. Liver, heart and kidney phospholipids

A comparison of the results obtained in the present investigation (A) with those obtained by other workers: [(B) Marinetti, Erbland \& Stotz (1958); (C) Hanahan, Dittmer \& Warashina (1957); (D) Dawson (1960)]. -, Denotes not detected. All figures are molar \% of total lipid phosphorus.

\begin{tabular}{|c|c|c|c|c|c|c|c|c|c|c|}
\hline & \multicolumn{4}{|c|}{ Liver } & \multicolumn{3}{|c|}{ Heart } & \multicolumn{3}{|c|}{ Kidney } \\
\hline & (A) & $\begin{array}{l}\text { (B) } \\
\text { Rat }\end{array}$ & $\begin{array}{l}\text { (C) } \\
\text { Rat }\end{array}$ & $\begin{array}{l}\text { (D) } \\
\text { Sheep }\end{array}$ & $\begin{array}{l}\text { (A) } \\
\text { Rat }\end{array}$ & $\begin{array}{l}\text { (B) } \\
\text { Rat }\end{array}$ & $\begin{array}{l}\text { (D) } \\
\text { Sheep }\end{array}$ & $\begin{array}{l}\text { (A) } \\
\text { Rat }\end{array}$ & $\begin{array}{l}\text { (B) } \\
\text { Rat }\end{array}$ & $\begin{array}{l}\text { (D) } \\
\text { Sheep }\end{array}$ \\
\hline $\begin{array}{l}\text { Phosphatidic acid-like } \\
\text { material }\end{array}$ & 5 & 3 & - & 3 & 11 & 10 & 14 & 7 & 5 & 7 \\
\hline $\begin{array}{l}\text { Phosphatidylethanolamine } \\
\text { and phosphatidylserine }\end{array}$ & 17 & 22 & 26 & 31 & 19 & 30 & 29 & 20 & 30 & 33 \\
\hline Complex phospholipids & 38 & - & $\dot{-}$ & - & 41 & - & - & $\mathbf{3 8}$ & - & - \\
\hline Lecithin and sphingomyelin & 33 & 66 & 60 & 59 & 23 & 49 & 46 & 26 & 55 & 51 \\
\hline $\begin{array}{l}\text { Inositol and other minor } \\
\text { phospholipids }\end{array}$ & 7 & 5 & 7 & 6 & 6 & 6 & 4 & 9 & 7 & 4 \\
\hline
\end{tabular}


There is general agreement between these results and those of other workers that the choline, ethanolamine and serine phospholipids together account for between 85 and $95 \%$, depending on the tissue. The remainder is represented by the inositol phospholipids and the phosphatidic acid-like material. In Table 4 it will be seen that the amounts of phosphatidic acid-like materials agree for any one tissue, notwithstanding the contrasts in the methods employed.

Table 4 shows that the major difference between the results of the present investigation and those obtained by other workers is the demonstration of the presence of complex phospholipids, which contain ethanolamine, serine and choline. This will account for the observed decrease in the proportion of phosphatidylethanolamine and phosphatidylserine and of lecithin and sphingomyelin as compared with the results of other workers. Collins (1960) has presented evidence showing that these complex phospholipids are not artifacts and has suggested that they are triester phospholipids. Evidence was also presented showing that chromatography on silicic acid could cause a breakdown of the complex phospholipids, which would account for the failure by other investigators to detect these compounds. Since tertiary phosphate esters are easily hydrolysed by $0 \cdot 2 \mathrm{~N}$-alkali at $35^{\circ}$ (Vernon, 1957) this would explain why the procedure described by Dawson (1960) does not distinguish between triester and diester phospholipids.

The presence of complex phospholipids has not only been demonstrated in animal tissues but also in yeast, a virus and a plant tissue. Hence it seems probable that this group of compounds is of universal occurrence.

\section{SUMMARY}

1. Analysis of the phospholipids of rat tissues agreed satisfactorily with published results except for the presence of a complex phospholipid fraction.

2. Complex phospholipids were shown to be present in rat tissues, egg yolk and allantoic membrane, influenza virus, human plasma, cabbage leaf, human brain, yeast and a freshwater crustacean.

3. The complex phospholipids constitute about
$40 \%$ of all phospholipid mixtures so far examined and a procedure for isolating derivatives of these materials is described.

We wish to thank Mr G. L. Ada of the Walter and Eliza Hall Institute, Melbourne, and the Director, Commonwealth Serum Laboratories, Melbourne, for the gift of materials, and the National Health and Medical Research Council for financial support. One of us (V.L.S.) had a Commonwealth Postgraduate Award and a grant from the University of Melbourne. We wish to express our appreciation for the technical assistance of Mrs M. Labutis and Miss T. B. G. Kaak.

\section{REFERENCES}

Ada, G. L. \& Perry, B. T. (1954). Aust. J. exp. Biol. med. Sci. $32,453$.

Carter, H. E., Haines, W. J., Ledyard, W. E. \& Norris, W. P. (1947). J. biol. Chem. 169, 77.

Cohn, E. J., Strong, L. E., Hughes, W. L., Mulford, D. J., Ashworth, J. N., Melin, M. \& Taylor, H. L. (1946). J. Amer. chem. Soc. 68, 459.

Cole, P. G., Lathe, G. H. \& Ruthven, C. R. J. (1953). Biochem. J. 54, 449.

Collins, F. D. (1959a). Biochem. J. 72, 532.

Collins, F. D. (1959b). Biochem. J. 72, 281.

Collins, F. D. (1960). Nature, Lond., 188, 297.

Collins, F. D. \& Shotlander, V. L. (1960). J. Lipid Res. 1, 352.

Collins, F. D. \& Wheeldon, L. W. (1957). Biochem. J. 66, 441.

Collins, F. D. \& Wheeldon, L. W. (1958). Biochem. J. 70, 46.

Dawson, R. M. C. (1957). Biol. Rev. 32, 188.

Dawson, R. M. C. (1960). Biochem. J. 75, 45.

Dueul, H. J. (1955). The Lipids, vol. 2. New York: Interscience Publishers Inc.

Hanahan, D. J., Dittmer, J. C. \& Warashina, E. (1957). J. biol. Chem. 228, 685.

Marinetti, G. V., Erbland, J. \& Stotz, E. (1958). Biochim. biophys. Acta, 30, 642.

Sakagami, T., Shimojo, T. \& Yokoyama, A. (1959). J. Biochem., Tokyo, 46, 1607.

Taylor, W. E. \& McKibbon, J. M. (1953). J. biol. Chem. 201, 609.

Vernon, C. A. (1957). Spec. Pub. chem. Soc., Lond., no. 8, 17.

Wheeldon, L. W. \& Collins, F. D. (1957). Biochem. J. 66, 435.

Wheeldon, L. W. \& Collins, F. D. (1958). Biochem. J. 70, 43.

Wittcoff, H. (1951). The Phosphatides. New York: Reinhold Publishing Corp. 